\title{
Correction to: Clinical Trial and Postmarketing Safety of Onasemnogene Abeparvovec Therapy
}

\author{
John W. Day ${ }^{1}$. Jerry R. Mendell ${ }^{2,3,4} \cdot$ Eugenio Mercuri $^{5,6} \cdot$ Richard S. Finkel $^{7,8} \cdot$ Kevin A. Strauss $^{9,10,11,12}$. \\ Aaron Kleyn ${ }^{13}$. Sitra Tauscher-Wisniewski ${ }^{13}$. Francis Fonyuy Tukov ${ }^{13}$. Sandra P. Reyna ${ }^{13}$. Deepa H. Chand ${ }^{13,14}$
}

Published online: 23 December 2021

(c) The Author(s) 2021

\section{Correction to: Drug Safety (2021) 44:1109-1119 https://doi.org/10.1007/s40264-021-01107-6}

In the original publication of the article, footnote marker 'b' was incorrectly placed in rows 2 and 3 of Table 4 . The correct Table 4 is published here.

Table 4 Hepatotoxicity adverse events and laboratory findings

\begin{tabular}{|c|c|c|c|c|c|c|}
\hline Hepatotoxicity & $\operatorname{START}(N=15)$ & $\begin{array}{l}\text { STR1VE- } \\
\text { EU } \\
(N=33)\end{array}$ & $\begin{array}{l}\text { STR1VE- } \\
\text { US } \\
(N=22)\end{array}$ & $\operatorname{SPR} 1 \mathrm{NT}(N=30)$ & $\begin{array}{l}\text { STR1VE- } \\
\text { AP } \\
(N=2)\end{array}$ & Total $(N=102)$ \\
\hline Reported AEs & $4(26.7 \%)$ & $18(54.5)$ & $7(31.8)$ & $8(26.7)^{\mathrm{a}}$ & 0 & $37(36.3)$ \\
\hline Elevations in LFT results (not reported as AEs) & $10(66.7)$ & $12(36.4)$ & $13(59.1)$ & $19(63.3)$ & 1 & $54(52.9)$ \\
\hline Postdosing elevations in LFT results & $15(100)$ & $29(87.9)$ & $20(90.9)$ & $26(86.7)$ & 0 & $90(90.0)$ \\
\hline $\begin{array}{l}\text { Elevations in LFT results at baseline (prior to } \\
\text { dosing) }\end{array}$ & $9(60.0)$ & $22(66.7)$ & $5(22.7)$ & $20(66.7)$ & 0 & $56(54.9)$ \\
\hline
\end{tabular}

AEs adverse events, LFTs liver function tests, $U L N$ upper limit of normal

${ }^{a}$ One of these events did not have laboratory abnormalities that were reported

${ }^{b}$ LFTs included analysis of aspartate aminotransferase, alanine aminotransferase, and bilirubin; all were $<2 \times$ ULN

The original article can be found online at https://doi.org/10.1007/ s40264-021-01107-6.

John W. Day

jwday@ stanford.edu

1 Department of Neurology, Stanford University Medical Center, MC 5979, 213 Quarry Road, Palo Alto, CA 94304, USA

2 Center for Gene Therapy, Nationwide Children's Hospital, Columbus, OH, USA

3 Department of Pediatrics, Ohio State University, Columbus, $\mathrm{OH}$, USA

4 Department of Neurology, Ohio State University, Columbus, $\mathrm{OH}, \mathrm{USA}$

5 Department of Paediatric Neurology and Nemo Clinical Centre, Catholic University, Rome, Italy

6 Centro Clinico Nemo, Fondazione Policlinico Gemelli IRCCS, Rome, Italy
7 Department of Pediatrics, Nemours Children's Hospital, Orlando, FL, USA

8 Center for Experimental Neurotherapeutics, St. Jude's Children's Research Hospital, Memphis, TN, USA

9 Clinic for Special Children, Strasburg, PA, USA

10 Penn Medicine-Lancaster General Hospital, Lancaster, PA, USA

11 Department of Pediatrics, University of Massachusetts School of Medicine, Worcester, MA, USA

12 Department of Molecular, Cell \& Cancer Biology, University of Massachusetts School of Medicine, Worcester, MA, USA

13 Novartis Gene Therapies, Inc., Bannockburn, IL, USA

14 Department of Pediatrics, Washington University School of Medicine and St. Louis Children's Hospital, St. Louis, MO, USA 
Open Access This article is licensed under a Creative Commons Attribution 4.0 International License, which permits use, sharing, adaptation, distribution and reproduction in any medium or format, as long as you give appropriate credit to the original author(s) and the source, provide a link to the Creative Commons licence, and indicate if changes were made. The images or other third party material in this article are included in the article's Creative Commons licence, unless indicated otherwise in a credit line to the material. If material is not included in the article's Creative Commons licence and your intended use is not permitted by statutory regulation or exceeds the permitted use, you will need to obtain permission directly from the copyright holder. To view a copy of this licence, visit http://creativecommons.org/licenses/by/4.0/. 